\title{
Impact of past HBV exposure on virological response to combined interferon ribavirin therapy in patients with chronic HCV genotype 4
}

\author{
M. Said ${ }^{1}$, M. S. El-Raziky ${ }^{1}$, M. Abdel-Hamid ${ }^{2}$, Y. Saad ${ }^{1 *}$, M. Hashem ${ }^{3}$, S. Zakaria ${ }^{1}$, M. K. Mohamed ${ }^{4}$, \\ G. Esmat ${ }^{1}$
}

${ }^{1}$ Endemic Medicine Department and Hepatology, Cairo University, Cairo, Egypt;

${ }^{2}$ Microbiology Department, El-Menia University, El-Menia, Egypt;

${ }^{3}$ Department of Epidemiology and Preventive Medicine, University of Maryland School of Medicine, Baltimore, USA;

${ }^{4}$ Department of Community Medicine, Ain Shams University, Cairo, Egypt.

Email: *drysaad99@yahoo.com

Received 12 June 2011; revised 16 July 2011; accepted 26 July 2011.

\section{ABSTRACT}

Aim: is to investigate if past exposure to $\mathrm{HBV}$ in chronic HCV infection promotes the progression of liver disease and influences Interferon (INF) response or not. Methods: 185 patients with chronic HCV were recruited and randomized into 2 groups, group I was treated with PEG-IFN alfa-2b plus ribavirin and group II with $3 \mathrm{MU} / \mathrm{TIW}$ IFN alfa-2b plus ribavirin. All patients had HBsAg negative \& patients had HBc Ab positive tested for $\mathrm{HBsAb}$. Patients with $\mathrm{HBc} \mathrm{Ab}$ (n = 37) were tested for serum HBV DNA. Pretreatment liver biopsy and Immunohistochemistry was performed for detection of HBsAg and HBcAg using monoclonal antibodies. Demographic and laboratory data were collected. Results: 70/185 (38\%) patients had Anti-HBc, $37(20 \%)$ had isolated anti-HBc and none of the 37 subjects with isolated anti-HBc had serum HBV DNA. Sustained Viral Response (SVR) was achieved in 32/70 (46\%) and 46/115 (40\%) in anti-HBc seropositive and seronegative patients respectively, in conventional IFN group SVR was $37 \%$ and $39 \%$ in past HBV exposed patients and unexposed respectively, in PEG IFN group SVR was 59\% and $41 \%$ in past HBV exposed patients and unexposed respectively. Among anti-HBc and anti-HBs seropositive patients SVR was 10/12 [83\%] and 4/21 [19\%] $p=0.004$ in PEG and conventional IFN respectively. Marked fibrosis was diagnosed in $20 \%$ past HBV exposed patients versus $10 \%$ in unexposed patients $(p=0.01)$. Conclusion: past HBV exposure promotes the progression of liver disease but has no effect on the SVR to antiviral therapy in chronic HCV genotype 4 patients.
Keywords: HCV Genotype 4; Past HBV Exposure; Response to Interferon Therapy

\section{INTRODUCTION}

Hepatitis $\mathrm{C}$ virus (HCV) infection is a chronic disease affecting 270 - 300 million people worldwide [1]. About $85 \%$ of those exposed to HCV become chronically infected and only $15 \%$ clear the virus. Chronic hepatitis and liver cirrhosis have been documented in $70 \%$ and $20 \%$, respectively, of those chronically infected $[2,3]$. Egypt has an overall HCV antibody prevalence around $15 \%$ in the general population [4-7] and genotype 4 has been identified in about $90 \%$ of HCV isolates [8-12]. Despite recent improvements in antiviral therapy with interferon and ribavirin, only about half of those who meet the criteria for treatment will respond to therapy. The mechanism responsible for the resistance to treatment and/or relapse of hepatitis after withdrawal of antiviral therapy may be host and/or virus related [13-15]. A possible factor influencing responsiveness of $\mathrm{HCV}$ positive patients to antiviral therapy may be co-infection with HBV [16]. Concurrent infection with the two viruses may worsen the prognosis and result in a less favorable outcome to antiviral treatment [17-19]. Moreover, some patients who are HBsAg negative but hepatitis B core antibody (anti- $\mathrm{HBc}$ ) positive are usually regarded as having occult HBV infection [20,21]. Some investigators have suggested that occult (in apparent) HBV infection correlates with a lack of response to interferon treatment in patients with chronic hepatitis $\mathrm{C}$ $[22,23]$.

Hepatitis B virus (HBV) is endemic in Egypt. The HBV markers (presence of either anti-HBc and/or HBs $\mathrm{Ag}$ ) were present in $24 \%$ of villagers in a study conducted in the Nile delta [24]. In a more recent serosur- 
veillance among Egyptian nationals working in the tourism industry the prevalence of serologic markers for currently asymptomatic or past HBV infection alone was $21 \%$ and of markers for both HBV and HCV was $6.9 \%$ [25].

To our knowledge, no studies have evaluated the role of past exposure to hepatitis B in HCV genotype 4 infected individuals. We therefore investigated whether past exposure to hepatitis B virus in individuals infected with $\mathrm{HCV}$ genotype 4 influences the response to interferon therapy.

\section{PATIENTS AND METHODS}

\subsection{Selection of Patients}

Chronically infected HCV naïve patients ( $>18$ years old and $<60$ years) who had detectable levels of serum HCV-RNA, HCV antibodies and undetectable HbsAg, elevated serum transaminase for at least six months and a histological diagnosis of chronic hepatitis with or without liver cirrhosis were eligible for the study. Exclusion criteria included: decompensated liver disease, hemoglobin $<13 \mathrm{~g} \cdot \mathrm{dL}^{-1}$ for men and $<12 \mathrm{~g} \cdot \mathrm{dL}^{-1}$ for women, white blood cell count of $<3000 / \mathrm{mm}^{3}$, neutrophil count of $<1500 / \mathrm{mm}^{3}$, or platelet count of $<100,000 /$ $\mathrm{mm}^{3}$. Patients who had had hepatitis B surface antigen (HBsAg), autoimmune hepatitis, hemochromatosis, Wilson's disease, $\alpha 1$-antitrypsin deficiency, aalcoholic liver disease, and drug induced liver disease, active Schistosomiasis, or hepatic tumors were excluded. Patients with poorly controlled diabetes mellitus or hypertension or under care of a psychiatrist were also excluded.

\subsection{Study Design and Treatment Regimen}

Two hundred and fifty patients were recruited in randomized, open label clinical trial to receive standard or pegylated interferon (alfa-2b \& alfa-2a) with ribavirin; it was conducted at the National Hepatology and Tropical Medicine Research Institute (NHTMRI), Cairo Egypt in collaboration with the International Health Division, University of Maryland, and School of Medicine. The study was approved by the institutional review board at both institutions and all study subjects provided written informed consent. The protocol conformed to the ethical guidelines of the 1975 Declaration of Helsinki. It was found that severe fibrosis, presence of steatosis, treatment with standard interferon and higher serum AFP were all independently and negatively associated with SVR. Level of pretreatment AFP, being a biological and noninvasive marker, could be incorporated into the routine assessment of factors predictive of treatment response [26].

To investigate whether past exposure to hepatitis B among the HCV infected study cohort has influenced the responsiveness to antiviral therapy, we performed a secondary analysis on a 185 out of 250 patients previously recruited who were HbsAg negative subjects. Anti-HBc was detected in $70(38 \%)$ of these 185 subjects and remaining $115(62 \%)$ were $\mathrm{HBV}$ seronegative with no evidence of past exposure to HBV.

\subsection{Clinical Evaluation}

The patients were evaluated as outpatients after 1, 2, 4, 6, 8 and 12 weeks of initiation of treatment, every 4 weeks thereafter during treatment, and 4, 12, and 24 weeks after treatment was completed. Patients were followed up until week 72 to assess sustained responses.

\subsection{Laboratory Evaluation}

Biochemical and hematological testing were performed at the Viral Hepatitis Research Laboratory (VHRL) at the NHTMRI. Virological studies included a third- generation screening test for the detection of antibody to hepatitis $\mathrm{C}$ virus (anti-HCV) (Abbott HCV EIA 3.0/Ortho HCV ELISA 3.0). Testing for hepatitis B markers included Hepatitis B Surface Antigen (HBsAg), Hepatitis B Surface Antibody (anti-HBs), and Total Hepatitis B Core Antibody (anti-HBc). Hepatitis C virus-RNA tests, viral genotyping, and histological evaluation of biopsy specimens were performed as well. Serum HCV-RNA tests were determined before and during treatment in the patients who were treated for 48 weeks; and after therapy weeks at week 72 to assess sustained responses. Serum HCV RNA was measured by an in-house reverse-transcripttion-polymerase-chain-reaction (RT)-PCR assay [27]. The assay has a lower limit of detection of 100 viral copies $\mathrm{mL}^{-1}$. (RT)-PCR is a modification of the standard PCR that was developed to amplify RNA templates. The major steps of the (RT)-PCR assay are isolation of RNA, reverse transcription of RNA into cDNA, and amplification of the cDNA by PCR. Primer sets used in the PCR reaction are highly conserved and can detect genotypes 4, as previously published [27]. Quantitative RT-PCR (real-time PCR) was performed to test for the HCV viral load using the Cobas Amplicor Kits from Roche (Germany). Conventional qualitative PCR detection of HBV DNA was performed on sera from patients positive for isolated anti-HBc (Cobas Amplicor HBV Monitor Test (Roche Diagnostic systems, Pleasanton, CA). The lower limit of detection was 200 copies/ml. HBV DNA extraction from tissues was done by PCR for 9 patients with isolated anti-HBc and with lower limit of detection of 200 copies $\mathrm{ml}^{-1}$.

Liver biopsy was performed at the beginning and the end of follow-up. Pretreatment liver biopsy was performed and evaluated in parallel with those obtained at week 72. Determination of the stage of fibrosis and the grade of inflammation was accomplished using the Modified Knodell score in the form of 18 points for 
Histopathology Activity Index (HAI) and six points for fibrosis. Immunohistochemistry (IHC) was performed for the detection of hepatitis B surface and core antigens in liver biopsies using monoclonal antibodies.

\subsection{Assessment of Efficacy and End Point}

The primary end point was a sustained virologic response, defined as the absence of serum HCV RNA 24 weeks after treatment was completed. Secondary end points were normalization of the serum alanine aminotransferase concentration at week 24 and histologic improvement. The degree of hepatic inflammation and fibrosis was graded with a modified Knodell Histologic Activity Index. The inflammation score was obtained by combining the scores for the first three components of this index: portal, periportal, and lobular inflammation. The scores could range from 0 to 18 , with higher scores indicating more severe abnormalities. The degree of fibrosis was graded as 0 , no fibrosis; 1 , portal fibrosis; 3 , bridging fibrosis; or 4, cirrhosis. Histologic improvement was defined as a decrease of at least two points in the inflammation score, as compared with the score for the pretreatment biopsy specimen. The biochemical response and the sustained combined biochemical and virologic response were also assessed.

\subsection{Statistical Analysis}

Intention-to-treat analysis was used as the primary analysis for all measures of efficacy. Quantitative variables were expressed as means and standard deviation, compared using the student's t-test, Mann-Whitney U test or ANOVA test when appropriate. Fisher exact test was used to compare categorical variables, with stratification by center for comparisons between treatment groups and stratification by center and treatment group for other categorical variables. Pearson correlation was used to compare quantitative variables between the groups. All statistical tests were 2-tailed; $\mathrm{P}<0.05$ was considered statistically significant. We used SPSS, version 10.0 for windows.

\section{RESULTS}

The enrolled $185 \mathrm{HCV}$ chronically infected and HbsAg negative subjects were tested for Hepatitis B Core antibody. Anti-HBc was detected in $70(38 \%)$ of the 185 subjects, 37 (20\%) were isolated anti-HBc, and $33(18 \%)$ were anti-HBs and anti-HBc seropositive. The remaining $115(62 \%)$ were HBV seronegative with no evidence of past exposure to HBV. None of the 37 subjects with isolated anti-HBc had HBV DNA detected in their sera by conventional qualitative PCR. The pretreatment characteristics of the patients were similar among patients with or without past exposure to hepatitis B in HCV genotype 4 infected individuals (Table 1).

Virological response: An overall sustained virological response (SVRs) (primary end point) of $42 \%(78 / 185)$

Table 1. Baseline characteristics of patients with chronic hepatitis $\mathrm{C}$ with or without positive markers of past HBV.

\begin{tabular}{|c|c|c|c|}
\hline $\begin{array}{l}\text { Characteristics of chronically in- } \\
\text { fected HCV naive patients }\end{array}$ & $\begin{array}{c}\text { HBV sero-negative } \\
\mathrm{N}(\%)=115(62)\end{array}$ & $\begin{array}{c}\text { Isolated anti-HBc } \\
\mathrm{N}(\%)=37(20)\end{array}$ & $\begin{array}{c}\text { Anti-HBs \& anti-HBc seropositive } \\
\qquad \mathrm{N}(\%)=33(18)\end{array}$ \\
\hline Age mean (SD), y & $37.6(8.5)$ & $41.2(8.6)$ & $43.4(8.2)$ \\
\hline \multicolumn{4}{|l|}{ Sex, No $(\%)$} \\
\hline Men & $89(77)$ & $31(84)$ & $28(85)$ \\
\hline Women & $26(23)$ & $6(16)$ & $5(15)$ \\
\hline \multicolumn{4}{|l|}{ Residence, No (\%) } \\
\hline Rural & $55(48)$ & $18(49)$ & $19(58)$ \\
\hline No $(\%)$ with active schistosomiasis & $18(16)$ & $8(22)$ & $5(15)$ \\
\hline Serum ALT mean (SD) & $104(70)$ & $117(62)$ & $115(72)$ \\
\hline Serum AST mean (SD) & $64(39)$ & $69(29)$ & $72(45)$ \\
\hline HCV RNA mean (IU/ml) & $2 \times 10^{6}$ & $0.4 \times 10^{6}$ & $0.5 \times 10^{6}$ \\
\hline No (\%) HBeAb & - & $23(62.2)$ & $20(60.6)$ \\
\hline Serum HBV DNA & NA & NEGATIVE $\dagger$ & NA \\
\hline Tissue HBV DNA & NA & NEGATIVE $!$ & NA \\
\hline Hepatomegaly & $27(24)$ & $9(24)$ & $9(27)$ \\
\hline Spenomegaly & $18(16)$ & $5(14)$ & $4(12)$ \\
\hline Liver Histology§ HAI No (\%) Minimal & $11(10)$ & $4(11)$ & $3(9)$ \\
\hline Mild & $76(66)$ & $20(54)$ & $20(61)$ \\
\hline Moderate & $27(23)$ & $12(32)$ & $7(21)$ \\
\hline Severe & $1(1)$ & $1(3)$ & $3(9)$ \\
\hline Fibrosis No (\%) Minimal & $15(13)$ & $88(77)$ & $12(10)$ \\
\hline Moderate & - & $29(78)$ & $8(22)$ \\
\hline Marked & $2(6)$ & $25(76)$ & $6(18)$ \\
\hline
\end{tabular}

†No Serum HBV DNA was detected in subjects with isolated anti-HBc ( $=37)$; $¥$ No Tissue HBV DNA was detected in 9 patients with isolated anti-HBc; $\S$ One hundred and eighty five patients had pretreatment liver biopsy. 
was achieved using combination therapy with interferon and ribavirin. SVR was achieved in $32(46 \%)$ of the 70 patients with laboratory evidence of prior exposure to HBV and 46 patients (40\%) of the 115 patients without prior exposure $(p=0.5)$. Among patients treated with standard interferon the SVR was $37 \%$ in the HBV exposed and $39 \%$ in the HBV unexposed patients. Also, among the pegylated interferon treated group no statistically significant differences in the SVR of patients with past exposure compared to those without HBV exposure $59 \%(17 / 29)$ vs. 41\% (26/63) respectively (Table 2). Whereas, among the 33 patients who were Anti-HBs \& anti-HBc seropositive significantly more patients in the pegylated interferon treated group achieved a SVR compared to those treated with standard interferon group $(10 / 12$ [83\%] versus 4/21 [19\%] $p=0.004)$ respectively.

Virological relapse was similar in both arms of the study. A total of the $11(12 \%)$ of the 93 patients in the standard interferon group and $13(14 \%)$ of the 92 patients in the pegylated interferon group relapsed after having undetectable HCV RNA in their sera. Of the seventy $\mathrm{HBV}$ exposed patients four $(5.7 \%)$ had virological relapse versus $20(17 \%)$ of the $115 \mathrm{HBV}$ unexposed patients.

Among patients with history of past exposure HBV infection (anti-HBc with or without anti-HBs), 3\%, 77\%, and $20 \%$ were diagnosed as having minimal, moderated or marked fibrosis respectively while $13 \%, 77 \%, 10 \%$ of HBV seronegative patients were diagnosed as having minimal, moderated or marked fibrosis respectively (Table 3).

Table 2. Percent of patients with sustained virological response (SVR) after 72 weeks.

\begin{tabular}{ccc}
\hline Characteristics & $\begin{array}{c}\text { Anti-HBs and/or anti-HBC } \\
\text { seropositive } \\
\text { N (\%) }=\mathbf{7 0}(\mathbf{3 8})\end{array}$ & $\begin{array}{c}\text { HBV } \\
\text { seronegative } \\
\mathbf{N}(\mathbf{\%})=\mathbf{1 1 5}(\mathbf{6 2})\end{array}$ \\
\hline Standard Interferon & $37 \%$ & $39 \%$ \\
PEG INF & $59 \%$ & $41 \%$ \\
Total N (\%) & $32(46 \%)$ & $46(40 \%)$ \\
\hline
\end{tabular}

Table 3. Stages of fibrosis in chronically infected HCV naive patients with or without past exposure to hepatitis B virus.

\begin{tabular}{ccc}
\hline Characteristics & $\begin{array}{c}\text { Anti-HBC \&or anti-HBs } \\
\text { seropositive } \\
\text { N (\%) = 70 (38) }\end{array}$ & $\begin{array}{c}\text { HBV } \\
\text { seronegative } \\
\text { N (\%)= 115 (62) }\end{array}$ \\
\hline Minimal (stages 0-1) & $2(3)$ & $15(13)$ \\
Moderate (stages 2-4) & $54(77)$ & $88(77)$ \\
Marked* (stages 4-6) & $14(20)$ & $12(10)$ \\
\hline
\end{tabular}

$* \mathrm{P}=0.01$.

\section{DISCUSSION}

The primary goal of therapy for chronic HCV infection is viral eradication. Treatment of chronic HCV infection has significantly improved over the past several years with combination PEG-IFN and ribavirin therapy. SVR is achievable in nearly half of patients with genotype 1 and about $80 \%$ of those with genotypes 2 and 3 [28-30]. In a published meta-analysis of randomized, controlled, open-label treatment trials of naive patients with chronic HCV genotype 4 [31,32] the overall SVR to combination therapy using PEG-IFN and ribavirin therapy was $55 \%$. In another study to evaluate the treatment response and duration of therapy in patients with HCV genotype 4, a randomized, double-blind study of PEG-IFN alfa-2b and ribavirin was performed [33] and SVR was achieved in $29 \%, 66 \%$, and $69 \%$ of patients treated for 24,36 , and 48 weeks, respectively. Thus, the data available suggest that treatment response to genotype 4 lies somewhere between that for genotype 1 and genotypes 2 and 3 .

To date, the reason for the differences in response of various genotypes to antiviral therapy remains unclear as it is not known why certain genotypes respond more favorably to antiviral therapy than other genotypes. The outcome of therapy may be influenced by a dynamic complex relationship that exists between the pharmacological characteristics of the therapeutic regimen, viral kinetics, and host immune responses, or concurrent co-infection with HBV. It was observed that the presence of markers indicating past $\mathrm{HBV}$ infection (anti HBV antibodies) was associated with a reduced rate of treatment response [23], in more recent study past history of HBV infection had no influence on the efficacy of treatment with IFN-alpha and ribavirin through Clearance of HCV from serum and from PBMC [34].

We evaluated the effectiveness of interferon treatment in HCV genotype 4 chronically infected naive patients with past exposure to hepatitis $\mathrm{B}$ virus infection. We found more than one third (38\%) of our study participants had laboratory evidence of past exposure to HBV. The percentage of SVR achieved was similar in the group of patients with or without evidence of past exposure to HBV infection. SVRs were also similar in the pegylated interferon treated and the standard interferon treated groups. However, patients treated with peg interferon and having both hepatitis B core and surface antibodies had a significantly better SVR than that observed in the standard interferon treated patients $(p=0.004)$.

Although virological relapse was similar in both treatment arms of the study, yet a significantly lower virological relapse rate was observed in the HBV exposed patients compared to the HBV unexposed patients.

Finally our results showed that the prevalence of anti-HBV antibodies was parallel to the severity of liver 
disease, with significantly more HBV exposed patients (anti-HBc with or without anti-HBs) with marked fibrosis and this was still true after adjustment for age, sex and history of schistosomiasis, the presence of positive anti-HBc was an important independent risk factor for the development of severe fibrosis in patients with $\mathrm{HCV}$ related chronic liver disease. Conclusion: these data suggest that past exposure to HBV infection may promote the progression of liver disease but has no effect on the SVR to combination therapy in chronic hepatitis C serotype 4 patients residing in areas where HBV infection is endemic.

\section{ACKNOWLEDGEMENTS}

We would like to thank clinicians of the National Hepatology \& Tropical Medicine Research Institute (NHTMRI) for taking care of the patients at the field hospital and at the NHTMRI; the laboratory staff working at the study site for their collaboration. We would like to thank the Schering Plough pharmaceutical company for supplying pegylated interferon alfa-2b (Peg Intron, Schering-Plough, Kenilworth, NJ) and ribavirin (Rebetol, Schering-Plough) and thank the Roche Laboratories for supplying pegylated interferon alfa-2a (PEGASYS1, F. Hoffmann La Roche Ltd., Basel, Switzerland) and ribavirin (COPEGU S1, F. Hoffmann La Roche Ltd., Basel, Switzerland) in collaboration with Maryland University.

\section{REFERENCES}

[1] Ryan, K.J. and Ray, C.G. (Eds). (2004) Sherris medical microbiology. 4th Edition, McGraw Hill, 551-552.

[2] Lauer, G.M. and Walker, B.D. (2001) Hepatitis C virus infection. New England Journal of Medicine, 345, 41-52. doi:10.1056/NEJM200107053450107

[3] Seeff, L.B. (2002) Natural history of chronic hepatitis. Hepatology, 36, 35-46. doi:10.1053/jhep.2002.36806

[4] Abdel-Aziz, F., Habib, M., Mohamed, M.K., AbdelHamid, M., Gamil, F., Madkour, S. et al. (2000) Hepatitis $\mathrm{C}$ virus (HCV) infection in a community in the Nile Delta: Population description and HCV prevalence. Hepatology, 32, 111-115. doi:10.1053/jhep.2000.8438

[5] Habib, M., Mohamed, M.K., Abdel-Aziz, F., Magder, L.S., Abdel-Hamid, M., Gamil, F. et al. (2001) Hepatitis $\mathrm{C}$ virus infection in a community in the Nile Delta: Risk factors for seropositivity. Hepatology, 33, 248-253. doi:10.1053/jhep.2001.20797

[6] Nafeh, M.A., Medhat, A., Shehata, M., Mikhail, N.N., Swifee, Y., Abdel-Hamid, M. et al. (2000) Hepatitis C in a community in Upper Egypt: I. Cross-sectional survey. American Journal of Tropical Medicine and Hygiene, 63, 236-241.

[7] Medhat, A., Shehata, M., Magder, L.S., Mikhail, N., Abdel-Baki, L., Nafeh, M. et al. (2002) Hepatitis C in a community in Upper Egypt: Risk factors for infection. American Journal of Tropical Medicine and Hygiene, 66, 633-638.

[8] Dusheiko, G.M. (1994) Progress in hepatitis C research. Lancet, 344, 605-606.
doi:10.1016/S0140-6736(94)91984-4

[9] McOmish, F., Yap, P.L., Dow, B.C., Follett, E.A., Seed, C., Keller, A.J. et al. (1994) Geographical distribution of hepatitis $\mathrm{C}$ virus genotypes in blood donors: An international collaborative survey. Journal of Clinical Microbiology, 32, 884-892.

[10] Mellor, J., Holmes, E.C., Jarvis, L.M., Yap, P.L. and Simmonds, P. (1995) Investigation of the pattern of hepatitis $\mathrm{C}$ virus sequence diversity in different geographical regions: Implications for virus classification. The International HCV Collaborative Study Group. Journal of General Virology, 76, 2493-2507.

[11] Quinti, I., El-Salman, D., Monier, M.K., Hackbart, B.G., Darwish, M.S., El-Zamiaty, D. et al. (1997) HCV infection in Egyptian patients with acute hepatitis. Digestive Diseases and Sciences, 42, 2017-2023. doi:10.1023/A: 1018897813268

[12] Zekri, A.R., Bahnassy, A.A., Ramadan, A.S., El-Bassuoni, M., Badran, A., Madwar, M.A. (2001) Hepatitis C virus genotyping versus serotyping in Egyptian patients. Infection, 29, 24-26. doi:10.1007/s15010-001-0010-8

[13] Farci, P., Alter, H.J., Wong, D.C., Miller, R.H., Govindarajan, S., Engle, R. et al. (1994) Prevention of hepatitis $\mathrm{C}$ virus infection in chimpanzees after antibodymediated in vitro neutralization. Proceedings of the $\mathrm{Na}$ tional Academy of Sciences of the United States of America, 1, 7792-7796. doi:10.1073/pnas.91.16.7792

[14] Weltman, M.D., Brotodihardjo, A., Crewe, E.B., Farrell, G.C., Bilous, M., Grierson, J.M. et al. (1995) Coinfection with hepatitis $\mathrm{B}$ and $\mathrm{C}$ or $\mathrm{B}, \mathrm{C}$ and delta viruses results in severe chronic liver disease and responds poorly to interferon-alpha treatment. Journal of Viral Hepatitis, 2, 39-45. doi:10.1111/j.1365-2893.1995.tb00070.x

[15] Liaw, Y.F. (1995) Role of hepatitis C virus in dual and triple hepatitis virus infection. Hepatology, 22, 11011108.

[16] Fukuda, R., Ishimura, N., Niigaki, M., Hamamoto, S., Satoh, S., Tanaka, S. et al. (1999) Serologically silent hepatitis $\mathrm{B}$ virus coinfection in patients with hepatitis $\mathrm{C}$ virus-associated chronic liver disease: Clinical and virological significance. Journal of Medical Virology, 58, 201-207.

doi:10.1002/(SICI)1096-9071(199907)58:3<201::AID-J $\mathrm{MV} 3>3.0 . \mathrm{CO} ; 2-2$

[17] Mrani, S., Chemin, I., Menouar, K., Guillaud, O., Pradat, P., Borghi, G. et al. (2007) Occult HBV infection may represent a major risk factor of non-response to antiviral therapy of chronic hepatitis C. Journal of Medical Virology, 79, 1075-1081. doi:10.1002/jmv.20943

[18] Miura, Y., Shibuya, A., Adachi, S., Takeuchi, A., Tsuchihashi, T., Nakazawa, T. et al. (2008) Occult hepatitis $\mathrm{B}$ virus infection as a risk factor for hepatocellular carcinoma in patients with chronic hepatitis $\mathrm{C}$ in whom viral eradication fails. Hepatology Research, 38, 546-556. doi:10.1111/j.1872-034X.2007.00316.x

[19] Branco, F., Mattos, A.A., Coral, G.P., Vanderborght, B., Santos, D.E., Franca, P. et al. (2007) Occult hepatitis B virus infection in patients with chronic liver disease due to hepatitis $\mathrm{C}$ virus and hepatocellular carcinoma in Brazil. Arquivos de Gastroenterologia, 44, 58-63. doi:10.1590/S0004-28032007000100013

[20] Liang, T.J., Blum, H.E. and Wands, J.R. (1990) Ch- 
aracterization and biological properties of a hepatitis B virus isolated from a patient without hepatitis B virus serologic markers. Hepatology, 12, 204-212.

[21] Zhang, Y.Y., Hansson, B.G., Kuo, L.S., Widell, A. and Nordenfelt, E. (1993) Hepatitis B virus DNA in serum and liver is commonly found in Chinese patients with chronic liver disease despite the presence of antibodies to HBsAg. Hepatology, 17, 538-544. doi:10.1002/hep. 1840170403

[22] Cacciola, I., Pollicino, T., Squadrito, G., Cerenzia, G., Orlando, M.E. and Raimondo, G. (1999) Occult hepatitis $\mathrm{B}$ virus infection in patients with chronic hepatitis $\mathrm{C}$ liver disease. New England Journal of Medicine, 341, 22-26. doi:10.1056/NEJM199907013410104

[23] Zignego, A.L., Fontana, R., Puliti, S., Barbagli, S., Monti, M., Careccia, G. et al. (1997) Relevance of inapparent coinfection by hepatitis B virus in alpha interferontreated patients with hepatitis $\mathrm{C}$ virus chronic hepatitis. Journal of Medical Virology, 51, 313-318.

[24] Kamel, M.A., Miller, F.D., El Masry, A.G., Zakaria, S., Khattab, M., Essmat, G., et al. (1994) The epidemiology of Schistosoma mansoni, hepatitis B and hepatitis C infection in Egypt. Annals of Tropical Medicine and $\mathrm{Pa}$ rasitology, 88, 501-509.

[25] El-Sayed, N.M., Gomatos, P.J., Rodier, G.R., Wierzba, T.F., Darwish, A., Khashaba, S. et al. (1996) Seroprevalence survey of Egyptian tourism workers for hepatitis $\mathrm{B}$ virus, hepatitis $\mathrm{C}$ virus, human immunodeficiency virus, and Treponema pallidum infections: Association of hepatitis $\mathrm{C}$ virus infections with specific regions of Egypt. American Journal of Tropical Medicine and Hygiene, 55, 179-184.

[26] Gad, R.R., Males, S., El Makhzangy, H., Shouman, S., Hasan, A., Attala, A. et al. (2008) Predictors of a sustained virological response in patients with genotype 4 chronic hepatitis C. Liver International, 28, 1478-3223.

[27] Abdel-Hamid, M., Edelman, D.C., Highsmith, W.E. et al. (1997) Optimization, assessment, and proposed use of a direct nested reverse transcribtion-polymease chain re- action protocol for the detection of hepatitis $\mathrm{C}$ virus. Journal of Human Virology, 1, 58-65.

[28] Manns, M.P., McHutchison, J.G., Gordon, S.C., Rustgi, V.K., Shiffman, M., Reindollar, R. et al. (2001) Peginterferon alfa-2b plus ribavirin compared with interferon alfa- $2 b$ plus ribavirin for initial treatment of chronic hepatitis C: A randomised trial. Lancet, 358, 958-965. doi:10.1016/S0140-6736(01)06102-5

[29] Fried, M.W., Shiffman, M.L., Reddy, K.R., Smith, C., Marinos, G., Gonçales, F.L. Jr et al. (2002) Peginterferon alfa-2a plus ribavirin for chronic hepatitis $\mathrm{C}$ virus infection. New England Journal of Medicine, 347, 975982. doi:10.1056/NEJMoa020047

[30] Hadziyannis, S.J. and Koskinas, J.S. (2004) Differences in epidemiology, liver disease and treatment response among HCV genotypes. Hepatology Research, 29, 129 135. doi:10.1016/j.hepres.2004.02.011

[31] Shobokshi, O.A. (2003) Hepatis C virus genotype 4. Saudi Medical Journal, 24, 79-80.

[32] Alfaleh, F.Z., Hadad, Q., Khuroo, M.S., Algamedi, A., Alashgar, H., et al. (2004) Peginterferon alpha-2b plus ribavirin compared with interferon alpha-2b plus ribavirin for initial treatment of chronic hepatitis $\mathrm{C}$ in Saudi patients commonly infected with genotype 4. Liver International, 24, 568-574. doi:10.1111/j.1478-3231.2004.0976.x

[33] Kamal, S.M., El Tawil, A.A., Nakano, T., He, Q., Rasenack, J., Hakam, S.A. et al. (2005) Peginterferon \{alpha\}-2b and ribavirin therapy in chronic hepatitis $\mathrm{C}$ genotype 4: Impact of treatment duration and viral kinetics on sustained virological response. Gut, 54, 858866. doi:10.1136/gut.2004.057182

[34] Majda-Stanisławska, E., Bednarek, M., Jóźwiak, B., Sidorkiewicz, M., Piekarska, A. and Kuydowicz, J.E. (2006) Effect of interferon alfa and ribavirin treatment on hepatitis $\mathrm{C}$ virus RNA in serum and peripheral blood mononuclear cells in children with chronic hepatitis $\mathrm{C}$. Acta Gastroenterol Belg, 69, 187-190. 